\title{
Review
}

\section{Artemisinin resistance, some facts and opinions}

\author{
Antonella Pantaleo ${ }^{1}$, Maria Carmina Pau ${ }^{2}$, Huynh Dinh Chien ${ }^{3}$, Francesco Turrini ${ }^{4}$ \\ ${ }^{1}$ Department of Biomedical Sciences, University of Sassari, Sassari, Italy \\ ${ }^{2}$ Department of Clinical and Experimental Medicine, University of Verona, Verona, Italy \\ ${ }^{3}$ Biomedical Institute, Medical School, Hue University, Hue City, Vietnam \\ ${ }^{4}$ Department of Oncology, University of Turin, Turin, Italy
}

\begin{abstract}
Resistance to artemisinin derivatives (ARTs) in malaria disease is currently defined as a delayed parasite clearance following artemisinin combined therapy (ACT). Although ACT is still widely effective, the first evidence of artemisinin resistance was described in 2009 in Southeast Asia. Since then, resistance to ARTs / ACT has been monitored showing an increasing trend. The demonstrated resistance to all drugs that are currently associated to ART, the ambiguous finding that ART resistance is observed only in presence of resistance to the partner drug, the lack of a mechanistic rationale to choose the partner drugs and the lack of markers with known specificity and sensitivity to monitor ART resistance, represent the most worrisome issues.
\end{abstract}

Key words: artemisinin; delayed clearance of parasites; artemisinin combined therapy.

J Infect Dev Ctries 2015; 9(6):597-599. doi:10.3855/jidc.7015

(Received 13 April 2015 - Accepted 18 May 2015)

Copyright (C) 2015 Pantaleo et al. This is an open-access article distributed under the Creative Commons Attribution License, which permits unrestricted use, distribution, and reproduction in any medium, provided the original work is properly cited.

\section{Introduction}

Worldwide introduction of artemisinin derivatives (ART) improved the effectiveness of this therapy both in uncomplicated and in severe malaria saving a large number of lives and leading to a net reduction of prevalence in many countries. Natural products containing ART have been used in China and in malaria endemic European regions such as Sardinia since centuries; although high rates of recrudescence after ARTs treatment (from $4 \%$ to $30 \%$ ) have been repeatedly reported [1-5], the evidence of ARTs resistance has only recently been outlined. As a matter of fact, ART resistance, defined as a delayed clearance of parasites (DPC) after therapy, has been observed on the Thailand/Cambodia border in 2009 and correlated to higher recrudescence rates in a small cohort of patients [6]. Currently, evidences of artemisinin resistance have been identified in many countries of Southeast Asia such as at the border between Myanmar and India. Despite a demonstrable increase of DPC prevalence in this region, patients generally respond to artemisinin combinatory therapies (ACT). Notably, in these areas the resistance to combinatory drugs is often present and the risk of developing multidrug resistance is therefore substantial [7].
It is our opinion that the management of ART resistance is particularly troublesome because of two major issues: (i) lack of markers for epidemiological and diagnostic uses; (ii) lack of drugs with proven synergism to ART or at least with no negative interactions.

\section{Markers of artemisinin resistance}

It is very difficult to isolate artemisinin resistant strains from patients with a demonstrable therapeutic failure; since no laboratory markers with known sensitivity and specificity are available, it is important to underline that the assessment of ART resistance is more complex and more prone to errors than in the case of any other antimalarial drugs.

Among the available markers of ART resistance the measurement of $\mathrm{ART} \mathrm{IC}_{50}$ or estimates of the time required by ART to kill parasites in short term ex vivo cultures can provide information; however, these assays need a stringent inter-laboratory standardization and are easily affected by the inconsistent adaptation of parasite to culture conditions [7].

An additional limit is posed by the difficulty to discriminate between recrudescence due to:

(ii) therapeutic failure to ARTs, (ii) therapeutic failure to the partner drug; (iii) re-infection; (iv) 
inadequate drug uptake/absorption. To discriminate between therapeutic failure and re-infection is clearly more difficult in areas with high prevalence and low seasonality of malaria.

The finding and the validation of new markers to diagnose ART resistance is therefore mandatory, but the fact that the mechanism of action of ART is nearly unknown [8] and ART-resistant strains isolated from patients are generally not available represent a clear disadvantage. As the search of new markers cannot be based on a definite rationale, DPC (in vivo and in vitro) still represents the golden standard, although its sensitivity and specificity is still undetermined.

More recently, a mutation on the K13-Propeller locus has been observed to be associated to DPC in Cambodia [9]; subsequently, additional mutations on the same gene have been observed in other regions in South Asia [10-16]. This promising marker is currently used in association with DPC to identify ART resistance but both still require a substantial clinical validation. Wide clinical trials to correlate DPC and K13 mutations with confirmed ART resistance are therefore needed to assess the isolated and cumulative performances of the markers [16]. Unfortunately the intrinsic complexity of those markers do not favor the sustainability and the implementation of the large clinical trials that should be required to validate and to assign precise performances to available makers. Table 1 outlines the current state of the technical tools available to estimate the presence of ART resistance.

\section{Drugs for combinatory therapy}

Following the alarming evidence on the possible spreading of ART resistant strains, the use of combinatory ART therapy (ACT) has been strongly advised by health authorities and it is now widely used. Lack of information on the mechanism of action of ART, however, limits again a rational choice of the partner drug; and possible negative interferences between drugs cannot be excluded [16]. This issue is even more relevant as most of the available antimalarial drugs already displayed manifest resistance [17] and as ART resistance is observed only in presence of a demonstrated resistance to the partner drug [7]. The observation that ART activity is functionally related to the hemoglobin metabolism of the parasite poses further concern on the choice of the partner drug as 4-aminoquinolinic compounds interfere with this pathway and have showed negative interaction in vitro [18]. Table 2 displays the ACT therapies currently in use.

In conclusion, the emergence of a clinically relevant ART resistance may easily harm the recent advances obtained in the cure and control of malaria. Differently to the resistance observed for other antimalarial drugs, ART resistance appears subtle and particularly difficult to assess due to the lack of clearcut clinical counterparts and specific diagnostic tools. Currently, observational studies to monitor the rate of recrudescence taking in account the rates of spontaneous infection and the frequency of asymptomatic carriers are urgently needed to ensure the effectiveness of different therapeutic regimens and clinical validation of available markers.

Table 1. Technical tools to estimate ART resistance

\begin{tabular}{lll}
\hline Markers & Sensitivity/Specificity & Notes \\
\hline Parasitemia at day 28 & High sensitivity & $\begin{array}{l}\text { Specificity may be affected by false positive results } \\
\text { due to re-infection }\end{array}$ \\
DPC at 3, 5 days in vivo & Not available & $\begin{array}{l}\text { No clinical studies are available to determine their } \\
\text { diagnostic performances }\end{array}$ \\
\hline
\end{tabular}

Table 2. ACT types currently used in South East Asia

\begin{tabular}{lccc}
\hline \multirow{2}{*}{ Country } & \multicolumn{3}{c}{ ACT type (2015) } \\
\cline { 2 - 4 } & Artemether - Lumefantrine & Artesunate-Mefloquine & DHA-Piperaquine \\
\hline Cambodia & ----- & $\sqrt{ }$ & $\sqrt{ }$ \\
Laos & $\sqrt{ }$ & ---- & -1 \\
Myanmar & $\sqrt{ }$ & $\sqrt{ }$ & -1 \\
Thailand & $\sqrt{ }$ & ----- & $\sqrt{ }$ \\
Vietnam & ----- & & - \\
\hline
\end{tabular}




\section{References}

1. Diem Thuy le T, Na-Bangchang K, Hung le N, Chong M T, Van Thang N, Van Binh N, Danh P T (2007) Clinical efficacy of high dose monotherapy of oral dihydroartemisinin in uncomplicated falciparum malaria in Vietnam. Jpn J Infect Dis 60: 161-166

2. Mugittu K, Genton B, Mshinda H, Beck H P (2006) Molecular monitoring of Plasmodium falciparum resistance to artemisinin in Tanzania. Malar J 5: 126

3. Huong N M, Hewitt S, Davis T M, Dao LD, Toan TQ, Kim TB, Hanh N T, Phuong V N, Nhan DH, Cong LD (2001) Resistance of Plasmodium falciparum to antimalarial drugs in a highly endemic area of southern Viet Nam: a study in vivo and in vitro. Trans R Soc Trop Med Hyg 95: 325-329

4. Price R, Luxemburger C, van Vugt M, Nosten F, Kham A, Simpson J, Looareesuwan S, Chongsuphajaisiddhi T, White N $\mathrm{J}$ (1998) Artesunate and mefloquine in the treatment of uncomplicated multidrug-resistant hyperparasitaemic falciparum malaria. Trans R Soc Trop Med Hyg 92: 207-211

5. Bhattacharya P C, Pai-dhungat A J, Patel K (1997) Artemether in moderate to severe malaria: a multicenter trial in India. Southeast Asian J Trop Med Public Health 28: 736740

6. Dondorp A M, Nosten F, Yi P, Das D, Phyo A P, Tarning J, Lwin K M, Ariey F, Hanpithakpong W, Lee S J, Ringwald P, Silamut K, Imwong M, Chotivanich K, Lim P, Herdman T, An SS, Yeung S, Singhasivanon P, Day NP, Lindegardh N, Socheat D, White N J (2009) Artemisinin resistance in Plasmodium falciparum malaria. N Engl J Med 361: 455-467

7. World Health Organization (2014) WHO Status Report on artemisinin resistance. Available at: http://www.who.int/malaria/publications/atoz/status-repartemisinin-resistance-sep2014.pdf. Accessed on September 30, 2014.

8. Plowe CV (2014) Malaria: Resistance nailed. Nature 505: 3031

9. Ariey F, Witkowski B, Amaratunga C, Beghain J, Langlois A C, Khim N, Kim S, Duru V, Bouchier C, Ma L, Lim P, Leang R, Duong S, Sreng S, Suon S, Chuor C M, Bout D M, Menard S, Rogers WO, Genton B, Fandeur T, Miotto O, Ringwald P, Le Bras J, Berry A, Barale JC, Fairhurst RM, Benoit-Vical F, Mercereau-Puijalon O, Menard D (2014) A molecular marker of artemisinin-resistant Plasmodium falciparum malaria. Nature 505: 50-55

10. Takala-Harrison S, Jacob CG, Arze C, Cummings MP, Silva JC, Dondorp AM, Fukuda M M, Hien TT, Mayxay M, Noedl H, Nosten F, Kyaw MP, Nhien NT, Imwong M, Bethell D, Se Y, Lon C, Tyner SD, Saunders DL, Ariey F, MercereauPuijalon O, Menard D, Newton PN, Khanthavong M, Hongvanthong B, Starzengruber P, Fuehrer H P, Swoboda P, Khan W A, Phy AP, Nyunt MM, Nyunt MH, Brown TS, Adams M, Pepin CS, Bailey J, Tan JC, Ferdig MT, Clark TG, Miotto O, MacInnis B, Kwiatkowski DP, White NJ, Ringwald P, Plowe CV (2015) Independent emergence of artemisinin resistance mutations among Plasmodium falciparum in Southeast Asia. J Infect Dis 211: 670-679

11. Ashley EA, Dhorda M, Fairhurst RM, Amaratunga C, Lim P, Suon S, Sreng S, Anderson J M, Mao S, Sam B, Sopha C, Chuor CM, Nguon C, Sovannaroth S, Pukrittayakamee S, Jittamala P, Chotivanich K, Chutasmit K, Suchatsoonthorn C, Runcharoen R, Hien TT, Thuy-Nhien NT, Thanh N V, Phu NH, Htut Y, Han KT, Aye KH, Mokuolu OA, Olaosebikan R R, Folaranmi OO, Mayxay M, Khanthavong M, Hongvanthong B, Newton P N, Onyamboko MA, Fanello CI,
Tshefu A K, Mishra N, Valecha N, Phyo A P, Nosten F, Yi P, Tripura R, Borrmann S, Bashraheil M, Peshu J, Faiz MA, Ghose A, Hossain MA, Samad R, Rahman MR, Hasan MM, Islam A, Miotto O, Amato R, MacInnis B, Stalker J, Kwiatkowski DP, Bozdech Z, Jeeyapant A, Cheah PY, Sakulthaew T, Chalk J, Intharabut B, Silamut K, Lee SJ, Vihokhern B, Kunasol C, Imwong M, Tarning J, Taylor WJ, Yeung S, Woodrow CJ, Flegg JA, Das D, Smith J, Venkatesan M, Plowe CV, Stepniewska K, Guerin, PJ, Dondor, A., Day NP, White N J (2014) Spread of artemisinin resistance in Plasmodium falciparum malaria. N Engl J Med 371: 411-423

12. Thriemer K, Hong NV, Rosanas-Urgell A, Phuc BQ, Ha do M, Pockele E, Guetens P, Van, NV, Duong TT, AmambuaNgwa A, D'Alessandro U, Erhart A (2014) Delayed parasite clearance after treatment with dihydroartemisinin-piperaquine in Plasmodium falciparum malaria patients in central Vietnam. Antimicrob Agents Chemother 58: 7049-7055

13. Tun KM, Imwong M, Lwin K M, Win AA, Hlaing TM, Hlaing T, Lin K, Kyaw MP, Plewes, K, Faiz MA, Dhorda M, Cheah PY, Pukrittayakamee S, Ashley EA, Anderson TJ, Nair S, McDew-White M, Flegg J A, Grist EP, Guerin P, Maude R J, Smithuis F, Dondorp AM, Day NP, Nosten F, White NJ, Woodrow CJ (2015) Spread of artemisinin-resistant Plasmodium falciparum in Myanmar: a cross-sectional survey of the K13 molecular marker. Lancet Infect Dis 15: 415-421

14. Phyo AP, Nkhoma S, Stepniewska K, Ashley EA, Nair S, McGready R, ler Moo C, Al-Saai S, Dondorp A M, Lwin KM, Singhasivanon P, Day N P, White NJ, Anderson TJ, Nosten F (2012) Emergence of artemisinin-resistant malaria on the western border of Thailand: a longitudinal study. Lancet 379: 1960-1966

15. Mbengue A, Bhattacharjee S, Pandharkar T, Liu H, Estiu G, Stahelin RV, Rizk SS, Njimoh DL, Ryan Y, Chotivanich K, Nguon C, Ghorbal M, Lopez-Rubio JJ, Pfrender M, Emrich S, Mohandas N, Dondorp AM, Wiest O, Haldar K (2015) A molecular mechanism of artemisinin resistance in Plasmodium falciparum malaria. Nature 520: 683-687

16. Dogovski C, Xie SC, Burgio G, Bridgford J, Mok S, McCaw JM, Chotivanich K, Kenny S, Gnädig N, Straimer J, Bozdech Z, Fidock DA, Simpson JA, Dondorp AM, Foote S, Klonis N, Tilley L (2015) Targeting the Cell Stress Response of Plasmodium falciparum to Overcome Artemisinin Resistance. PLoS Biol 13e: 1002132

17. Anderson TJ, Nair S, Qin H, Singlam S, Brockman A, Paiphun L, Nosten F (2005) Are transporter genes other than the chloroquine resistance locus (pfcrt) and multidrug resistance gene (pfmdr) associated with antimalarial drug resistance? Antimicrob Agents Chemother 49: 2180-2188

18. Haynes R K, Cheu K W, N'Da D, Coghi P, Monti D (2013) Considerations on the mechanism of action of artemisinin antimalarials: part 1--the 'carbon radical' and 'heme' hypotheses. Infect Disord Drug Targets 13: 217-277

\section{Corresponding author}

Antonella Pantaleo Department of Biomedical Sciences,

University of Sassari,

Via Muroni 25, 07100, Sassari, Italy

Phone: + 39079228651

Fax: + 39079228615

Email: apantaleo@uniss.it

Conflict of interests: No conflict of interests is declared. 